Tory

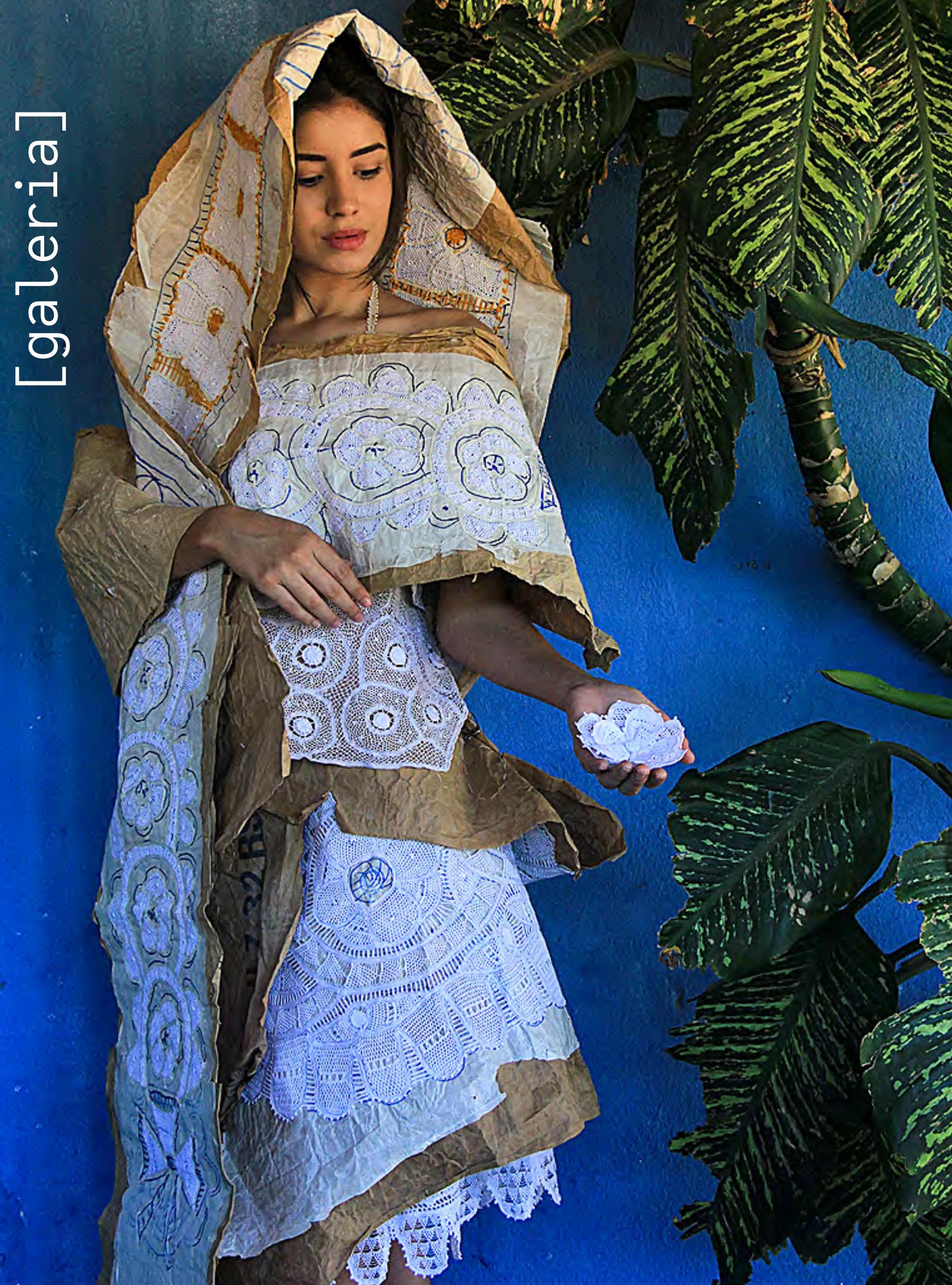




\section{Secos e Molhados}

Fotógrafo: Rogério Ortiz

Estilista: Romero Sousa

Artesã: Djanete Figueiredo

Performer: Andreza Aguida

Diretora de Arte: Kathia Castilho

Agradecimento: Carolina Sayama

Sonhar com imagens de moda como uma dança que não se faz só, produzindo uma "comunidade sem forma, inoperante, mas sensível", como diz o filósofo Kuniichi Uno (2018). 0 encontro é com a artesã Djanete Figueiredo. e o estilista Romero Sousa, ambos criadores paraibanos comprometidos com slow fashion. Em São Paulo, participam a pesquisadora Kathia Castilho e a artista e defensora da causa do albinismo Andreza Aguida. 

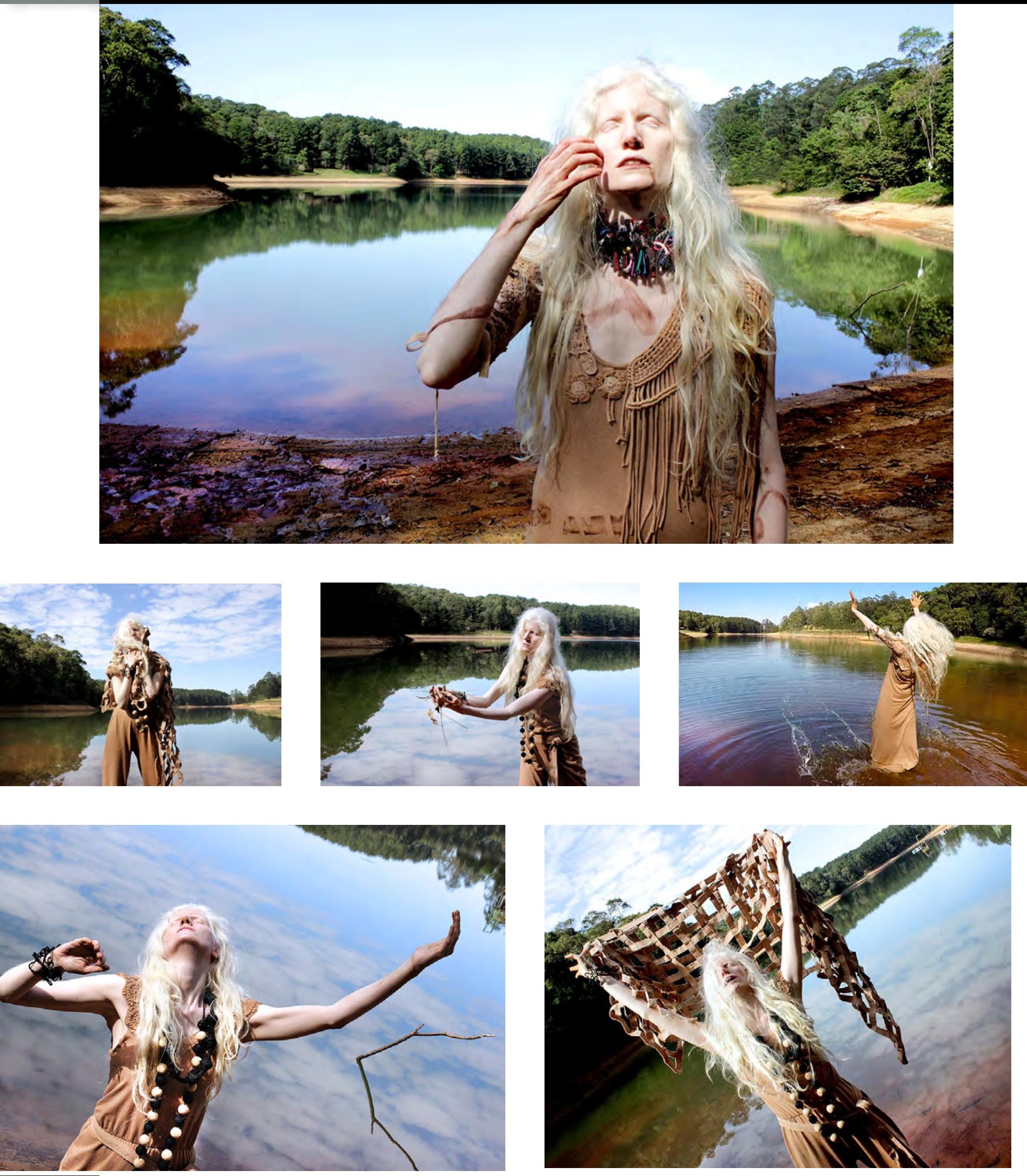